\begin{tabular}{|c|l|}
\hline Title & Effects of UV wavelength on cell damages caused by UV irradiation in PC12 cells \\
\hline Author(s) & Masuma, Runa; Kashima, Sakura; Kurasaki, Masaaki; Okuno, T sutomu \\
\hline Citation & $\begin{array}{l}\text { Journal of Photochemistry and Photobiology B: Biology, 125, 202-208 } \\
\text { https:/doi.org/10.1016/.jphotobiol.2013.06.003 }\end{array}$ \\
\hline Issue Date & 201308-05 \\
\hline Doc URL & http://hdl.handle.net/2115/53037 \\
\hline Type & article (author version) \\
\hline File Information & 2RMasuma.pdf \\
\hline
\end{tabular}

Instructions for use 


\section{Effects of UV wavelength on cell damages caused by UV irradiation in}

\section{PC12 cells}

\section{Runa Masumaa, Sakura Kashimaa, Masaaki Kurasakia,b*, Tsutomu Okunoc}

aEnvironmental Adaptation Science, Graduate School of Environmental Science, Hokkaido University, Sapporo 060-0810, Japan

bEnvironmental Adaptation Science, Faculty of Environmental Earth Science, Hokkaido University, Sapporo 060-0810, Japan

cHuman Engineering and Risk Management Group, , Kawasaki 214-8585, Japan

\footnotetext{
${ }^{*}$ :Address correspondence to:

Dr. Masaaki KURASAKI,
}

Group of Environmental Adaptation Science, Faculty of Environmental Earth Science, Hokkaido University, Sapporo 060-0810, Japan;

Phone: +81-11-706-2243, Fax: +81-11-706-4864; E-mail:kura@ees.hokudai.ac.jp 


\section{Abstract}

Ultraviolet (UV) radiations present in sunlight are a major etiologic factor for many skin diseases and induce DNA damage through formation of cyclobutane pyrimidine dimer (CPD). This study was conducted to determine the toxicological effects of different wavelengths $(250,270,290$, and $310 \mathrm{~nm}$ ) and doses of UV radiation on cell viability, DNA structure, and DNA damage repair mechanisms in a PC12 cell system. For this, we evaluated cell viability and CPD formation. Cell survival rate was markedly decreased 24 hours after UV irradiation in a dose-dependent manner at all wavelengths (except at $310 \mathrm{~nm}$ ). Cell viability increased with increasing wavelength in the following order: $250<270<290<310 \mathrm{~nm}$. UV radiation at $250 \mathrm{~nm}$ showed the highest cell killing ability, with a median lethal dose (LD50) of $120 \mathrm{~mJ} / \mathrm{cm}^{2}$. The LD50 gradually increased with increase in wavelength. Among the 4 wavelengths tested, the highest LD50 $\left(6,000 \mathrm{~mJ} / \mathrm{cm}^{2}\right)$ was obtained for $310 \mathrm{~nm}$. CPD formation decreased substantially with increasing wavelength. Among the 4 wavelengths, the proportion of CPD formation was highest at $250 \mathrm{~nm}$ and lowest at $310 \mathrm{~nm}$. On the basis of LD50 values for each wavelength, PC12 cells irradiated with UV radiation of 290 nm showed maximum DNA repair ability, whereas those irradiated with the 310-nm radiation did not show any repair ability. Toxicity of UV radiation varied with wavelengths and exposure doses.

Keywords: Ultraviolet wavelengths; PC12 cell; cell viability; cyclobutane dimer formation; DNA damage; DNA repair 


\section{Introduction}

Ultraviolet (UV) radiation induces basal and squamous cell carcinoma and cutaneous malignant melanoma in humans [1-3] and is therefore a major environmental concern. UV radiations exert their toxic effects by causing DNA damage, which depends mainly on the wavelength. The etiologically relevant UV wavelengths, which cause photoaging and photocarcinogenesis are UVA (315-400 nm), UVB (280-315 nm), and UVC (200-280 nm). The most energetic part of natural solar UV radiation is UVB [4], which is primarily responsible for induction of DNA damage [5]. DNA, which maximally absorbs radiation at wavelengths of 245$290 \mathrm{~nm}$, is one of the main cellular targets of UV radiations [6,7]. Owing to its wavelength, which is within the absorption peak of DNA [8], UVC is the most proficient in induction of DNA damage. Although solar UVC radiation cannot reach the Earth's surface, these harmful radiations are generated from artificial light sources such as arc welding lights, bactericidal lamps, and photocuring devices [9]. In contrast to UVB and UVC radiation, the mutagenic and carcinogenic effects of UVA result from generation of reaction-oxygen species (ROS) through the process of photosensitization [10,11]. Researchers have mainly focused on UVA and UVB radiation, and UVC remains poorly studied. Bio-analysis of toxicity of different wavelengths is expected to clarify cancer mechanisms, providing information that will be helpful in the fields of photobiology, dermatology, ophthalmology, and cosmetology.

DNA damage in cells exposed to UV radiation plays significant roles in cell-cycle arrest, activation of DNA repair, cell death, mutation and neoplastic transformation, and 
immunosuppression. These cellular processes are related to photoaging and photocarcinogenesis $[12,13]$. UV-mediated DNA damage is mainly attributed to the formation of cyclobutane pyrimidine dimers (CPDs) between adjacent thymine $(T)$ or cytosine $(C)$ residues, or to a lesser extent, formation of pyrimidine (6-4) pyrimidone photoproducts (6-4PPs) via direct absorption of UV photons by the DNA bases [14,15]. Accumulation of these lesions can lead to mutations. Approximately $70-80 \%$ of UV-induced DNA damage is caused by production of CPDs, the levels of which vary at different wavelengths [16]. Biologically, compared to UVA, UVB and UVC are more potent inducers of photocarcinogenesis, which leads to generation of an aggrandized amount of CPDs, because nucleobases only weakly absorb (104-fold) radiation above $320 \mathrm{~nm}[8,17-19]$. CPD production levels at different wavelengths should be investigated to clarify the relationships between cell viability, production of CPDs, and nuclear excision repair.

Generally, cells have the ability to preserve genomic integrity. In mammalian cells, nucleotide excision repair (NER) is the most important mechanism for repairing UV-generated CPDs and (6-4) photoproducts and is used to remove bulky DNA damage from the genome [20-22]. However, if DNA damage is too severe and cannot be repaired, the apoptotic pathway is triggered to prevent propagation of the damage [23,24]. UV-induced apoptosis depends upon the mitochondrial pathway, where p53 plays a leading role by either up-regulating apoptosis-promoting genes such as Bax and Fas/Apo-1 or down-regulating expression of BCL-2-suppressing genes [25-28]. 
To date, how different wavelengths of UV radiation affect the mechanism of toxicity caused by UV radiation has not been investigated. To assess the toxicological effects of the different UV wavelengths on organisms, we compared the DNA damage and CPD formation caused by UV radiations of wavelength $250 \mathrm{~nm}, 270 \mathrm{~nm}, 290 \mathrm{~nm}$, and $310 \mathrm{~nm}$, administered at different doses, in a PC12 cell system. To confirm whether each wavelength influenced UV cytotoxicity and UV-induced DNA damage, we performed the trypan blue exclusion test and enzyme-linked immunosorbent assay (ELISA) on the PC12 cells.

\section{Materials and Method}

\subsection{Materials}

PC12 cells, a rat pheochromocytoma cell line, were purchased from the American Type Culture Collection (USA and Canada). Dulbecco's Modified Eagle Medium (DMEM), streptavidin-conjugated peroxidase, ribonuclease A (RNase), ethidium bromide, and o-phenylenediamine dihydrochloride (OPD) were obtained from Sigma-Aldrich (St. Louis, MO, USA). Fetal bovine serum (FBS) was purchased from Hyclone (Rockville, MD, USA). Monoclonal antibody against CPDs was purchased from Cosmo-Bio Co., Ltd. (Japan). Biotinylated goat anti-mouse immunoglobulin was purchased from Amersham Pharmacia Biotech (Buckinghamshire, England). DNA markers were obtained from Promega (Madison, WI, USA), and proteinase K was obtained from Roche Diagnostica (Mannheim, Germany). Trypan blue stain solution $(0.5 \%)$ was purchased from Nacalai Tesque (Kyoto, Japan). All the other 
chemicals were of analytical reagent grade.

\subsection{Cell Culture}

PC12 cells were maintained in DMEM supplemented with 10\% FBS in a humidified incubator with $5 \% \mathrm{CO} 2$ at $37^{\circ} \mathrm{C}$. The cells were pre-incubated overnight in $35-\mathrm{mm}$ tissue culture dishes, after which the medium was replaced with DMEM containing 10\% FBS.

\subsection{UV-irradiation}

PC12 culture medium was changed by adding $2 \mathrm{~mL}$ phosphate-buffered saline, after washing twice with $2 \mathrm{~mL}$ of the same solution, because medium itself absorbed UV irradiation. Following addition of fresh medium, a xenon-lamp light source (MAX-301, Asahi Spectra, Tokyo, Japan), equipped with bandpass filters that isolate specific wavelength regions, was used as the UV source. Cells in the dishes were exposed to a narrow band with a width of approximately $10 \mathrm{~nm}$ at each different wavelength $(250,270,290$, and $310 \mathrm{~nm})$ of UV radiation.

Before exposure to each wavelength, irradiance at the position of the target cells was measured using a radiometer (IL 1400 A, International Light Technologies, Peabody, USA) connected to a silicon-photodiode detector (SEL033, International Light Technologies), and exposure duration was determined by measuring the irradiate dose. Irradiation doses were then established using the following formula: irradiation dose $\left(\mathrm{mJ} / \mathrm{cm}^{2}\right)=$ exposure time $(\mathrm{sec}) \times$ irradiance $\left(\mathrm{mW} / \mathrm{cm}^{2}\right)$. 
To determine the dose-effect relationship, 6 doses $\left(2,5,10,20,100\right.$, and $\left.200 \mathrm{~mJ} / \mathrm{cm}^{2}\right)$ of each of the tested wavelengths were applied to the PC12 cells, and then the cell viability test and ELISA were performed on the irradiated cells. Cells that were not UV irradiated and were maintained at room temperature during irradiation were used as control cells. After UV irradiation, cells were cultured in medium containing serum for $24 \mathrm{~h}$.

For determination of relative toxicity of the 4 different wavelengths, we quantified cell viability and the CPDs formed following UV irradiation with the 4 wavelengths, each applied at the same dose $\left(100 \mathrm{~mJ} / \mathrm{cm}^{2}\right)$ and culturing for different periods-10 $\min , 30 \mathrm{~min}, 1 \mathrm{~h}, 2 \mathrm{~h}, 4 \mathrm{~h}$, and $24 \mathrm{~h}$-in serum-containing medium.

The median lethal dose (LD50)—the dose required for killing $50 \%$ of the test cells—for 250 , 270,290 , and $310 \mathrm{~nm}$ radiations was estimated. Next, the DNA-repair (recovery rate) ability of the cells was evaluated on the basis of cell viability and CPD formation. For this, PC12 cells were irradiated with the 4 wavelengths at their respective LD50 and cultured for $10 \mathrm{~min}, 30 \mathrm{~min}, 1 \mathrm{~h}, 2$ $\mathrm{h}, 4 \mathrm{~h}$, and $24 \mathrm{~h}$ after each irradiance. The recovery rate was then calculated by comparing the amount of CPDs remaining at the end of each culture time to that observed at the initial time (10 $\min )$. Recovery rate was calculated by using the following equation ( Amount of CPDs at 10 min after UV irradiation - CPDs at final cultured time after UV irradiation) $\times 100$ 


\subsection{Cell Viability}

The trypan blue exclusion assay was used to evaluate cell viability. After UV irradiation, the cells were incubated in DMEM containing serum for different durations from 10 min up to $24 \mathrm{~h}$. After incubation, the cells were stained with $0.25 \%$ trypan blue solution in phosphate-buffered saline. Total cells and trypan blue-stained cells were counted using a hemocytometer (TC10 automated cell counter, Bio-Rad). Cell viability was expressed as a percentage of live cells against total cell number in each experiment. Each experiment was repeated 3-6 times. Cell viability was calculated using the following formula;

Live cells $(\%)=100 \times$ Viable cells $/$ Total cells

\subsection{Genomic DNA isolation from PC12 cells}

Following UV irradiation of PC12 cells, genomic DNA was isolated using the procedure described by Yamanoshita et al. [29] with some modifications. Cells were washed with $10 \mathrm{mM}$ Tris- $\mathrm{HCl}$ buffer $(\mathrm{pH} 7.4)$ containing $150 \mathrm{mM} \mathrm{NaCl}$ and then harvested using a scraper. The harvested cells were centrifuged at $1,500 \mathrm{rpm}$ for $5 \mathrm{~min}$, and the supernatants were removed. Subsequently, cells were incubated with $10 \mathrm{mM}$ Tris-HCl buffer ( $5 \mathrm{mM}$ Tris), $0.1 \mathrm{M}$ EDTA, $0.5 \%$ sodium dodecyl sulfate, and $20 \mu \mathrm{g} / \mathrm{mL}$ of pancreatic RNase for $15 \mathrm{~min}$ at $37^{\circ} \mathrm{C}$. Proteinase $\mathrm{K}$ $(100 \mu \mathrm{g} / \mathrm{mL})$ was added to the suspension, and the enzyme reaction was carried out for $3 \mathrm{~h}$ at $50^{\circ} \mathrm{C}$. The obtained DNA was resuspended in $89 \mathrm{mM}$ Tris- $\mathrm{HCl}$ buffer $(\mathrm{pH}$ 8.1) containing $1 \mathrm{mM}$ $\operatorname{EDTA}(1 \times$ TBE). 


\subsection{ELISA for quantification of CPD formation}

To the extracted DNA samples, $1 \times$ TBE was added to adjust the DNA concentration to 1 $\mu \mathrm{g} / \mu \mathrm{L}$. Next, DNA was denatured by heating on a hot plate at $100^{\circ} \mathrm{C}$ for 10 min and chilling immediately on ice for $15 \mathrm{~min}$. After denaturation, $46 \mu \mathrm{L} /$ well of $1 \times$ TBE and $4 \mu \mathrm{L}$ of denatured DNA were added to each well in a titer plate (2 wells for each sample), and the DNA solution was dried completely overnight at $37^{\circ} \mathrm{C}$.

CPDs were quantified via ELISA, which was used for detecting the direct binding of monoclonal antibodies to antigens. After overnight incubation, a titer plate was washed 3 times with $40 \mathrm{mM}$ Tris- $\mathrm{HCl}$ buffer ( $\mathrm{pH}$ 7.4) containing $150 \mathrm{mM} \mathrm{NaCl}$. To block unbound areas in each well of the titer plate, we added $100 \mu \mathrm{L}$ of $2 \%$ blocking reagent in the same buffer to the wells, and the solution was incubated for $30 \mathrm{~min}$ at $37^{\circ} \mathrm{C}$. First, antibodies against CPDs (diluted to $1: 1,000$ in the same buffer) were immobilized by incubation for $1 \mathrm{~h}$ at $37^{\circ} \mathrm{C}$. Next, the plate was washed 3 times with the same buffer. The second antibody, a biotinylated anti-mouse immunoglobulin (diluted to 1:500 in the same buffer) was added, and the plate was incubated for $1 \mathrm{~h}$ at $37^{\circ} \mathrm{C}$. Then, the plate was washed twice with the same buffer. After addition of streptavidin-conjugated peroxidase (diluted to 1:400 in the same buffer), the plate was incubated for $30 \mathrm{~min}$ at $37^{\circ} \mathrm{C}$. After washing the well 5 times with the same buffer, $0.1 \%$ OPD in $50 \mathrm{mM}$ phosphate-citrate buffer ( $\mathrm{pH} 5.0$ ) containing $0.03 \%$ sodium perborate was added into the wells. 
measured using a Microplate Reader (model 450; Bio-Rad).

\subsection{Statistical analysis}

Each value is expressed as the mean \pm SEM. Statistical analysis was performed using the unpaired $t$-test, followed by the $F$-test.

\section{Results}

\subsection{Cell viability evaluation}

To examine whether UV irradiation caused cell toxicity, we evaluated cell viability by staining irradiated PC12 cells with trypan blue $24 \mathrm{~h}$ after exposure to 4 different wavelengths of UV radiations at irradiation doses of $2-200 \mathrm{~mJ} / \mathrm{cm}^{2}$ (Fig. 1). Compared to the cell viability of the control, viability of irradiated cells was significantly lower at all irradiation doses (except $310 \mathrm{~nm}$ irradiation). The viability of PC12 cells was significantly reduced following exposure to high irradiation doses $\left(10,100\right.$, and $\left.200 \mathrm{~mJ} / \mathrm{cm}^{2}\right)$ of the $290-\mathrm{nm}$ radiation; however, cell viability was not significantly affected following exposure to the 310-nm radiation, irrespective of the dosage (Fig. 1).

In addition, to determine the relative toxicity of each wavelength tested, we quantified the viabilities of cells irradiated with the 4 different wavelengths at $100 \mathrm{~mJ} / \mathrm{cm}^{2}$ and incubated for 10 min up to $24 \mathrm{~h}$. Interestingly, irrespective of the wavelength used, the viabilities did not change significantly among the cells cultured for $10 \mathrm{~min}$ up to $4 \mathrm{~h}$ (data not shown). For cells cultured for 
$24 \mathrm{~h}$, the viability of cells irradiated with $250-\mathrm{nm}$ radiation was lower than that of cells exposed to 270-, 290-, and 310-nm radiations. Out of the cells irradiated with the 4 tested wavelengths, cells exposed to $310-\mathrm{nm}$ radiation showed the highest survival rate.

\subsection{Determination of LD50 of the 250-, 270-, 290-, and 310-nm radiations}

For determining the LD50 of the 4 tested wavelengths, we exposed PC12 cells to $25-800$ $\mathrm{mJ} / \mathrm{cm}^{2}$ of $250-, 270-$, and $290-\mathrm{nm}$ radiations and to $125-8000 \mathrm{~mJ} / \mathrm{cm}^{2}$ of the $310-\mathrm{nm}$ radiation. After irradiation, the cell viabilities were quantified. The LD50 values were calculated from the results of the cell viability assay and were $120,150,300$, and $6000 \mathrm{~mJ} / \mathrm{cm}^{2}$ for $250,270,290$, and $310 \mathrm{~nm}$, respectively (Fig. 2).

\subsection{Quantification of CPD formation by ELISA}

CPD formation in irradiated PC12 cells was analyzed using ELISA. As shown in Fig. 3A, CPD numbers were higher in the irradiated cells than in the control cell at $24 \mathrm{~h}$ cultured time after UV irradiation at $2-200 \mathrm{~mJ} / \mathrm{cm}^{2}$ irradiation doses, irrespective of the wavelength used. Among the 4 wavelengths tested, incidence of CPD formation was highest for the 250-nm radiation, and this increase in the amounts of CPDs formed was found to be statistically significant. Similar to the results for the 270- and 290-nm radiations, the 250-nm radiation induced high incidence of CPD formation, whereas the 310-nm radiation did not induce significant CPD formation at doses up to $200 \mathrm{~mJ} / \mathrm{cm}^{2}$. These results indicate that CPD formation increased in an irradiance-dependent 
manner. For determining relative CPD-inducing ability of the different wavelengths of UV radiation at different cultured time, we exposed PC12 cells to the 4 tested wavelengths at 100 $\mathrm{mJ} / \mathrm{cm}^{2}$ and incubated these irradiated cells for $10 \mathrm{~min}$ to $24 \mathrm{~h}$. By comparing the amount of CPDs formed in cells irradiated with the different wavelength, the magnitude of CPD formation was found to be the highest at $250 \mathrm{~nm}$ and the lowest at $310 \mathrm{~nm}$ at $24 \mathrm{~h}$ after UV irradiation, and CPD incidence at each tested wavelength showed the following order: $250 \mathrm{~nm}>290 \mathrm{~nm}>270$ $\mathrm{nm}>310 \mathrm{~nm}$ (Fig. 3B).

\subsection{Time course for LD50 of 250-, 270-, 290-, and 310-nm irradiation: cell viability and}

\section{CPD formation}

Cell viability gradually decreased for each wavelength with increasing culture time after UV irradiation at LD50 (Fig. 4). Among the 4 wavelengths, $310 \mathrm{~nm}$ at its LD50 significantly reduced the number of live cells at each culture time. The decrease in cell viability caused by the different wavelengths at their corresponding LD50 showed the following order: $310 \mathrm{~nm}>290 \mathrm{~nm}>250$ $\mathrm{nm}>270 \mathrm{~nm}$.

As shown in Fig. 5, CPD formation was significantly less with $270 \mathrm{~nm}$ and $290 \mathrm{~nm}$ over a 24-h culture time compared with that observed at the initial time (10 min after the UV irradiation). The recovery rate was approximately one-fifth-fold for 250-nm, two-third-fold for 270-nm, and half-fold for 290-nm radiations (Fig. 5). Cells irradiated with 310-nm UV radiation at its LD50 did not show any DNA repair ability. 


\section{Discussion}

The PC12 cell line is derived from rat pheochromocytoma tumor cells and is used to investigate cell toxicity of trace amounts of chemical substances. Many studies support this [30-32]. The PC12 cell line system is widely used in research because of its ability for rapid division, differentiation ability, and the presence of $\mathrm{Na}, \mathrm{K}$, and $\mathrm{Ca}$ channels and other membrane receptors [33,34]. PC12 cells have stronger UV resistance compared to other cell lines. Our results showed that PC12 cells could tolerate high LD50 (ranging from 120 to $6000 \mathrm{~mJ} / \mathrm{cm}^{2}$ ) of 250-310 nm wavelengths of UV radiations (Fig. 2). In contrast, for normal human epidermal keratinocytes (NHEKs) and porcine lens epithelial cells (LECs), the minimum LD50 values for 269-nm and 261.7-nm radiations were 1.64 and $1.77 \mathrm{~mJ} / \mathrm{cm}^{2}$, respectively, and for human LECs the minimum LD50 for the $267.5-\mathrm{nm}$ radiation was $8.86 \mathrm{~mJ} / \mathrm{cm}^{2}$ [35-37]. The LD50 of radiation for the PC12 cells was 50 times that for NHEKs and LECs.

The present study evaluated cell survival rate by using the PC12 cell system to clarify the relationship between cell viability and different wavelengths of UV radiation with respect to the irradiation dose and culture time after UV irradiation. Cell viability was significantly decreased at 250-, 270- and 290-nm radiations (Fig. 1). A previous report proposed that shorter wavelengths induce DNA damage directly through formation of CPDs or 6-4 photoproducts and that the cell killing effect of UV light is associated with the amount of pyrimidine dimers formed $[11,38]$. As previously reported, the cell killing action spectrum is close to the DNA absorption spectrum [39], 
and we hypothesized that DNA more prominently absorbed shorter wavelengths that directly induced DNA damage, which was responsible for the lethal effect of UVC irradiation on cells. We found that cell death depended on incubation time after UV irradiation, and cell death after irradiation was not significantly reduced until $24 \mathrm{~h}$ at all wavelengths. Cell death occurs from irreparable DNA damage that remains 24-48 $\mathrm{h}$ after UV exposure [19,40].

In this study, we confirmed that UV radiations induced DNA damage via CPD formation, an effect that was wavelength dependent. No wavelength-based chronological sequence was found as shown in Figs. $3 \mathrm{~A}$ and $\mathrm{B}$. The highest amount of CPDs was generated following exposure to the 250-nm radiation. CPD formation was more with the $290-\mathrm{nm}$ than with the $270-\mathrm{nm}$ radiation. DNA and proteins absorb is maximally at $260 \mathrm{~nm}$ and $280 \mathrm{~nm}$, respectively $[8,41]$. UV light is absorbed by tryptophan and tyrosine in proteins at $310 \mathrm{~nm}$ and $290 \mathrm{~nm}$, respectively $[42,43]$. The most effective wavelength, within the UVB range, for inducing DNA photoproducts in the basal layer of the epidermis is $300 \mathrm{~nm}$ [41]. The relationship between CPD formation and the irradiation dose was consistent with our expectation: the magnitude of CPD formation increased in a dose-dependent manner. This finding was supported by the results of Kubota et al. [19].

To determine DNA-repair ability of the PC12 cells, the LD50 values of the 4 tested wavelengths were determined from the results of the cell viability assays (Fig. 2). In this study, the LD50 values for $310 \mathrm{~nm}$ were 50, 40, and 20 times the LD50 values for 250, 270, and $290 \mathrm{~nm}$, respectively. It was previously reported that compared to UVC, UVA absorption by DNA is 105-fold times weak [44], and UVA is therefore proportionately far less effective in reducing cell 
viability. Our findings regarding the DNA-repair ability demonstrated that compared to the CPDs detected at 10 min after UV irradiation, the CPD numbers dramatically decreased during other culture times for all wavelengths (except $310 \mathrm{~nm}$ ) administered at their respective LD50 (Fig. 5). NER is the most important mechanism for elimination of structurally unrelated DNA lesions such as CPD from the genome within $24-48 \mathrm{~h}$ of UV irradiation $[22,19]$. In this study, cells irradiated with 290- and 270-nm radiations at their corresponding LD50 showed superior repair ability, whereas no repair was observed in cells irradiated with 310-nm radiation (Fig. 6). CPD Repair rates depend on genes and vary along the same gene sequence between adjacent base positions $[45,46]$. The exact reason behind the different repair rates following exposure to different wavelengths is still unclear. DNA-repair ability, assessed via a cytotoxicity assay, could not be explained on the basis of the cell viability results (Fig. 4).

In conclusion, the cytotoxicity of and DNA damage induction by 4 different wavelengths of UV radiation, administered at different irradiation doses, were found to be related. Among the 4 tested wavelengths, $250 \mathrm{~nm}$ and $310 \mathrm{~nm}$ showed the highest and lowest abilities for reduction of cell survival rate and induction of CPD formation, respectively. These results suggested that cells respond to different wavelengths of UV radiation via different mechanisms. Repair ability was higher at $290 \mathrm{~nm}$ and $270 \mathrm{~nm}$ than at $250 \mathrm{~nm}$, each administered at their respective LD50. Although $310 \mathrm{~nm}$ was less lethal to cells and induced less DNA damage than the other tested wavelength, long-term exposure (at the LD50) might cause severe and irreparable damage. Further investigation is needed to clarify the precise mechanism of CPD formation by each 
wavelength.

\section{Conflict of Interest}

The authors declare that there are no conflicts of interest.

\section{Acknowledgments}

This research was supported by Grants-in-Aid from the Japan Society for the Promotion of Science (No. 24350077 for Kurasaki). The authors also wish to thank Ms. Miyako Komori for her technical direction and advice.

\section{References}

[1] A.D. Woodhead, R.B. Setlow, M. Tanaka, Environmental factors in nonmelanoma and melanoma skin cancer, J. Epidemiol. 9 (1996) S102-114.

[2] C. Jhappan, F.P. Noonan, G. Merlino, Ultraviolet radiation and cutaneous malignant melanoma, Oncogene 22 (2003) 3099-3112.

[3] B.K. Armstrong, A. Kricker, The epidemiology of UV induced skin cancer, J. Phochem. Photobiol. B: Biol. 63 (2001) 8-18.

[4] E. Kvam, R.M. Tyrrell, Induction of oxidative DNA base damage in human skin cells by UV and near visible radiation, Carcinogenesis 18 (1997) 2379-2384. 
[5] S.E. Freeman, H. Hacham, R.W. Gange, D.J. Maytum, J.C. Sutherland, B.M. Sutherland, Wavelength dependence of pyrimidine dimer formation in DNA of human skin irradiated in situ with ultraviolet light, Proc. Natl. Acad. Sci. USA 86 (1989) 5605-5609.

[6] M.J. Peak, J.G. Peak, Solar-ultraviolet-induced damage to DNA, Photodermatology 6 (1989) 1-15.

[7] S. Tornaletti, G.P. Pfeifer, UV damage and repair mechanisms in mammalian cells, BioEssays 18 (1996) 221-228.

[8] J.D. Mallet, P.J. Rochette, Ultraviolet light-induced cyclobutane pyrimidine dimers in rabbit eyes, Photochem. Photobiol. 87 (2011) 1363-1368.

[9] Y. Matsumura, H.N. Ananthaswamy, Toxic effects of ultraviolet radiation on the skin, Toxicol. Appl. Pharmacol. 195 (2004) 298-308.

[10] M.I. Pygmalion, L. Ruiz, E. Popovic, J. Gizard, P. Portes, X. Marat, K. Lucet-Levannier, B. Mullet, J.P. Galey, Skin cell protection against UVA by Sideroxyl, a new antioxidant complementary to sunscreens, Free Rad. Biol. Med. 49 (2010) 1629-1637.

[11] F.R. de Gruijl, Photocarcinogenesis: UVA vs. UVB radiation, Skin. Pharmacol. Appl. Skin. Physiol. 15 (2002) 316-320.

[12] R. Pallela, Y. Na-Young, S.K. Kim, Anti-photoaging and photoprotective compounds derived from marine organisms, Mar. Drugs 8 (2010)1189-1202.

[13] K. Tanaka, J. Hasegawa, K. Asamitsu, T. Okamoto, Prevention of the Ultraviolet B-mediated skin photoaging by a nuclear factor kB inhibitor, Parthenolide, J. Pharmacol. Exp. Therap. 
315 (2005) 624-630.

[14] T. Douki, D. Perdiz, P. Grof, Z. Kuluncsics, E. Moustacchi, J. Cadet, E. Sage, Oxidation of guanine in cellular DNA by solar UV radiation: Biological role, Photochem. Photobiol. 70 (1999) 184-190.

[15] P.J. Rochette, J.P. Therrien, R. Drouin, D. Perdiz, N. Bastein, E.A. Drobetsky, E. Sage, UVA-induced cyclobutane pyrimidine dimers form predominantly at thymine-thymine dipyrimidines and correlate with the mutation spectrum in rodent cells, Nucl. Acids Res. 31 (2003) 2786-2794.

[16] A.A. Vink, L. Roza, Biological consequences of cyclobutane pyrimidine dimers, J. Photochem. Photobiol. B: Biol. 65 (2001) 101-104.

[17] A. Besaratinia, T.W. Synold, H.H. Chen, C. Chang, B. Xi, A.D. Riggs, G.P. Pfeifer, DNA lesions induced by UV A1 and B radiation in human cells: Comparative analysis in the overall genome and in the p53 tumor suppressor gene, PNAS 102 (2005) 10058-10063.

[18] J. Cadet, E. Sage, T. Douki, Ultraviolet radiation-mediated damage to cellular DNA, Mutation Res. 571 (2005) 3-17.

[19] Y. Kubota, C. Niwa, T. Ohnuma, Y. Ohko, T. Tatsuma, T. Mori, A. Fujishima, Protective effect of $\mathrm{TiO}_{2}$ particles on UV light induced pyrimidine dimer formation, J. Photochem. Photobiol. A: Chem. 141 (2001) 225-230.

[20] D. Mu, D.S. Hsu, A. Sancar, Reaction mechanism of human DNA repair excision nuclease, J. Biol. Chem. 271 (1996) 8285-8294. 
[21] G. Li, V.C. Ho, D.L. Mitchell, M.J. Trotter, V.A. Tron, Differentiation-dependent p53 regulation of nucleotide excision repair of keratinocytes, American J. Pathol. 150 (1997) $1457-1464$.

[22] J. de Boer, J.H.J. Hoeijmakers, Nucleotide excision repair and human syndromes, Carcinogenesis 21 (2000) 453-460.

[23] R. Gniadecki, M. Hansen, H.C. Wulf, Two pathways for induction of apoptosis by ultraviolet radiation in cultured human keratinocytes, The Soc. Inves. Dermatol. 109 (1997) 163-169.

[24] Y. Matsumura, H.N. Ananthaswamy, Molecular mechanisms of photocarcinogenesis, Front. Biosci. 7 (2002) D765-D783.

[25] L. Mullauer, P. Gruber, D. Sebinger, J. Buch, S. Wohlfart, A. Chott, Mutations in apoptosis genes : a pathogenetic factor for human disease, Mutan. Res. 488 (2001) 211-231.

[26] Y. Tsujimoto, S. Shimizu, Bcl-2 family: life-or-death switch, Febs. Lett. 466 (2000) 6-10.

[27] J.M. Adams, S. Cory, Life-or-death decisions by the Bcl-2 protein family, Trends Biochem. Sci. 26 (2001) 61-66.

[28] A. Zeigler, A.S. Jonson, D.j. Leffell, J.A. Simon, H.W. Sharma, J Kimmelman, L. Remington, T. Jacks, D.E. Brash, Sunburn and p53 in the onset of skin cancer, Nature 372 (1994) 773-776.

[29] O. Yamanoshita, M. Kurasaki, T. Saito, K. Takahashi, H. Sasaki, T. Hosokawa, M. Okabe, J. Mochida, T. Iwakuma, Diverse Effect of Tributyltin on apoptosis in PC12 cells, Biochem. Biophysic. Res. Commun. 272 (2000) 557-62. 
[30] O. Yamanoshita, T. Saito, K. Takahashi, T. Hosokawa, M. Okabe, K. Ito, M. Kurasaki, 2,4,5-Trichlorophenoxyacetic acid inhibits apoptosis in PC12 cells, Life Sci. 69 (2001) 403-408.

[31] Y. Sun, K. Takahashi, T. Hosokawa, T. Saito, M. Kurasaki, Diethyl phthalate enhances apoptosis induced by serum deprivation in PC12 cells, Bas. Clin. Pharmacol. Toxicol. 111 (2012) 113-119.

[32] M. Aoki, M. Kurasaki, T. Saito, S. Seki, T. Hosokawa, Y. Takahashi, H Fujita, T. Iwakuma, Nonylphenol enhances apoptosis induced by serum deprivation in PC12 cells, Life Sci. 74 (2004) 2301-2312.

[33] J.G. Duman, L. Chen, B. Hille, Calcium transport mechanisms of PC12 cells, J Gen Physiol 131 (2008) 307-323.

[34] T.J. Shafer, W.D. Atchison, Transmitter, ion channel and receptor properties of pheochromocytoma (PC12) cells: a model for neurotoxicological studies, Neurotoxicology 12 (1991) 473-492.

[35] K. Aoki, T. Nakanishi-Ueda, M. Tsuji, T. Okuno, Y. Saito, H. Yasuhara, Ultraviolet action spectrum and effect of EPC-K1 on ultraviolet radiation-induced injury in cultured normal human epidermal keratinocytes, Showa Univ. J. Med. Sci. 23 (2011) 1-10.

[36] T. Okuno, T. Nakanishi-Ueda, T. Ueda, H. Yasuhara, R. Koide. Ultraviolet action spectrum for cell killing of primary porcine lens epithelial cells, J. Occup. Health. 54 (2012) 181-186.

[37] T. Okuno, Ultraviolet action spectrum for cell killing in a human lens epithelial cell line, 
Industrial Health 45 (2007) 137-142.

[38] D.L. Mitchell, The relative cytotoxicity of (6-4) photoproducts and cyclobutane dimers in mammalian cells, Photochem. Photobiol. 48 (1988) 51-57.

[39] T.P. Coohill, M.J. Peak, G.P. Peak, The effects of the ultraviolet wavelengths of radiation present in sunlight on human cells in vitro, Photochem. Photobiol. 46 (1987) 1043-1050.

[40] H.L. Borges, R. Linden, J.Y.J. Wang, DNA damage-induced cell death: lessons from the central nervous system, Cell Res. 18 (2008) 17-26.

[41] T.M. Runger, U.P. Kappes, Mechanisms of mutation formation with long-wave ultraviolet light (UVA), Photodermatol. Photoimmunol. Photomed. 24 (2008) 2-10.

[42] D. Creed, The photophysics and photochemistry of the near UV-absorbing amino acids. I. Tryptophane and its simple derivatives, Photochem. Photobiol. 39 (1984a) 537-562.

[43] D. Creed, The photophysics and photochemistry of the near UV-absorbing amino acids. II. Tyrosine and its simple derivatives, Photochem. Photobiol. 39 (1984b) 563-5.

[44] J.C. Sutherland, K.P. Griffin, Absorption spectrum of DNA for wavelengths greater than 300 nm, Radiat. Res. 86 (1980) 399-409.

[45] S. Gao, R. Drouin, G.P. Holmquist, DNA repair rates mapped along the human PGK-1 gene at nucleotide resolution, Science 263 (1994) 1438-1440.

[46] S. Tornaletti, G.P. Pfeifer, Slow repair of pyrimidine dimers at p53 mutations hotspots in skin cancer, Science 263 (1994) 1436-1438. 


\section{Caption of Figures}

Fig. 1 Fig. 1 Viability of PC12 cells exposed to 4 different wavelengths of UV radiations at different doses $\left(2,5,10,20,100\right.$, and $\left.200 \mathrm{~mJ} / \mathrm{cm}^{2}\right) 24 \mathrm{~h}$ after irradiation. Error bars indicate SEM $(n=3)$. Asterisks denote values that are significantly different $\left({ }^{*} p<0.05,{ }^{* *} p<0.01,{ }^{* * *} p<0.001\right)$ from the control value.

Fig. 2 LD50 (mJ/cm2) of 250, 270, 290, and $310 \mathrm{~nm}$ UV radiations, which were determined from the number of viable PC12 cells present $24 \mathrm{~h}$ after UV irradiation with different doses. The LD50 values were $120,150,300$, and $6000 \mathrm{~mJ} / \mathrm{cm}^{2}$ for $250,270,290$, and $310 \mathrm{~nm}$, respectively. Error bars indicate SEM $(n=3-4)$.

Fig. 3 CPD formation (A) $24 \mathrm{~h}$ after UV irradiation with 250, 270, 290, and $310 \mathrm{~nm}$ UV radiations at doses of $2-200 \mathrm{~mJ} / \mathrm{cm}^{2}$ doses $(n=3)$. Asterisks denote values significantly different $\left({ }^{*} p<0.05\right.$, ${ }^{* * *} p<0.001$ ) from the control value. (B) Comparison of CPD formation in cells irradiated with 4 different wavelengths of UV radiation $\left(100 \mathrm{~mJ} / \mathrm{cm}^{2}\right) 24 \mathrm{~h}$ after irradiation $(n=4)$. Asterisks denote significantly different values $\left({ }^{*} p<0.05,{ }^{* * *} p<0.001\right)$. Error bars indicate SEM.

Fig. 4 Viability of PC12 cells after UV irradiation with 4 different wavelengths at their LD50 doses. Error bars indicate SEM $(n=3)$. PC12 cells were cultured for different durations after UV irradiation. ${ }^{*} p<0.05,{ }^{* *} p<0.01,{ }^{* * *} p<0.001$ indicate significant differences from the control value.

Fig. 5 Comparison of CPD formation in PC12 cells irradiated with 4 different wavelengths of UV radiation applied at their respective LD50 $\left(120 \mathrm{~mJ} / \mathrm{cm}^{2}\right.$ for $250 \mathrm{~nm}, 150 \mathrm{~mJ} / \mathrm{cm}^{2}$ for $270 \mathrm{~nm}, 300$ $\mathrm{mJ} / \mathrm{cm}^{2}$ for $290 \mathrm{~nm}$, and $6000 \mathrm{~mJ} / \mathrm{cm}^{2}$ for $\left.310 \mathrm{~nm}\right)$. Error bars indicate SEM $(n=3)$. Asterisks denote values significantly different $\left({ }^{*} p<0.05\right)$ from the initial time $(10 \mathrm{~min})$. 
Fig. 6 CPDs (\%) remaining in PC12 cells irradiated with 4 different wavelengths of UV radiations at their respective LD50 and cultured for different periods. Here, a 10-min culture period is considered the initial time ( $0 \%$ recovery), and recovery rate was evaluated by calculating the percentage of CPDs remaining at the end of each culture period, which was then compared to the CPD percentage observed at initial time. 


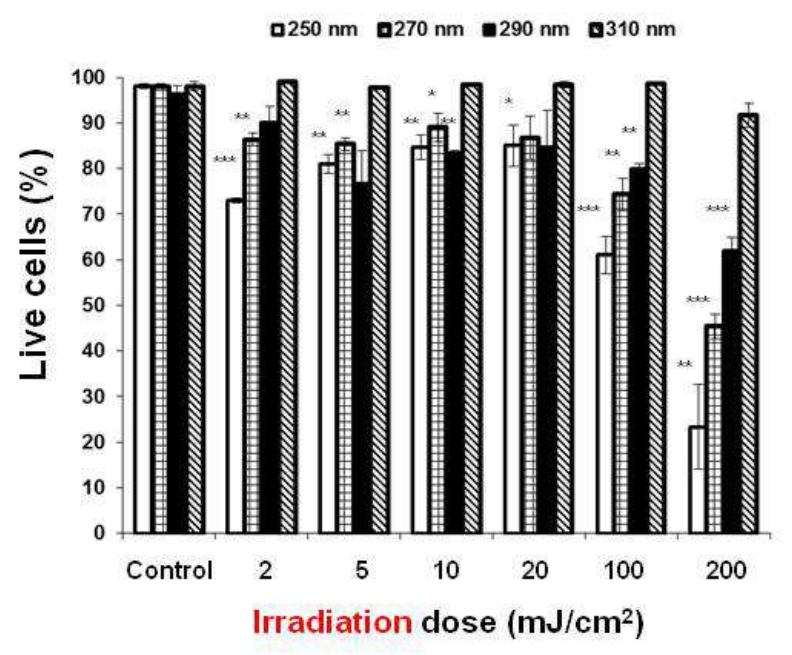

Fig. 1 


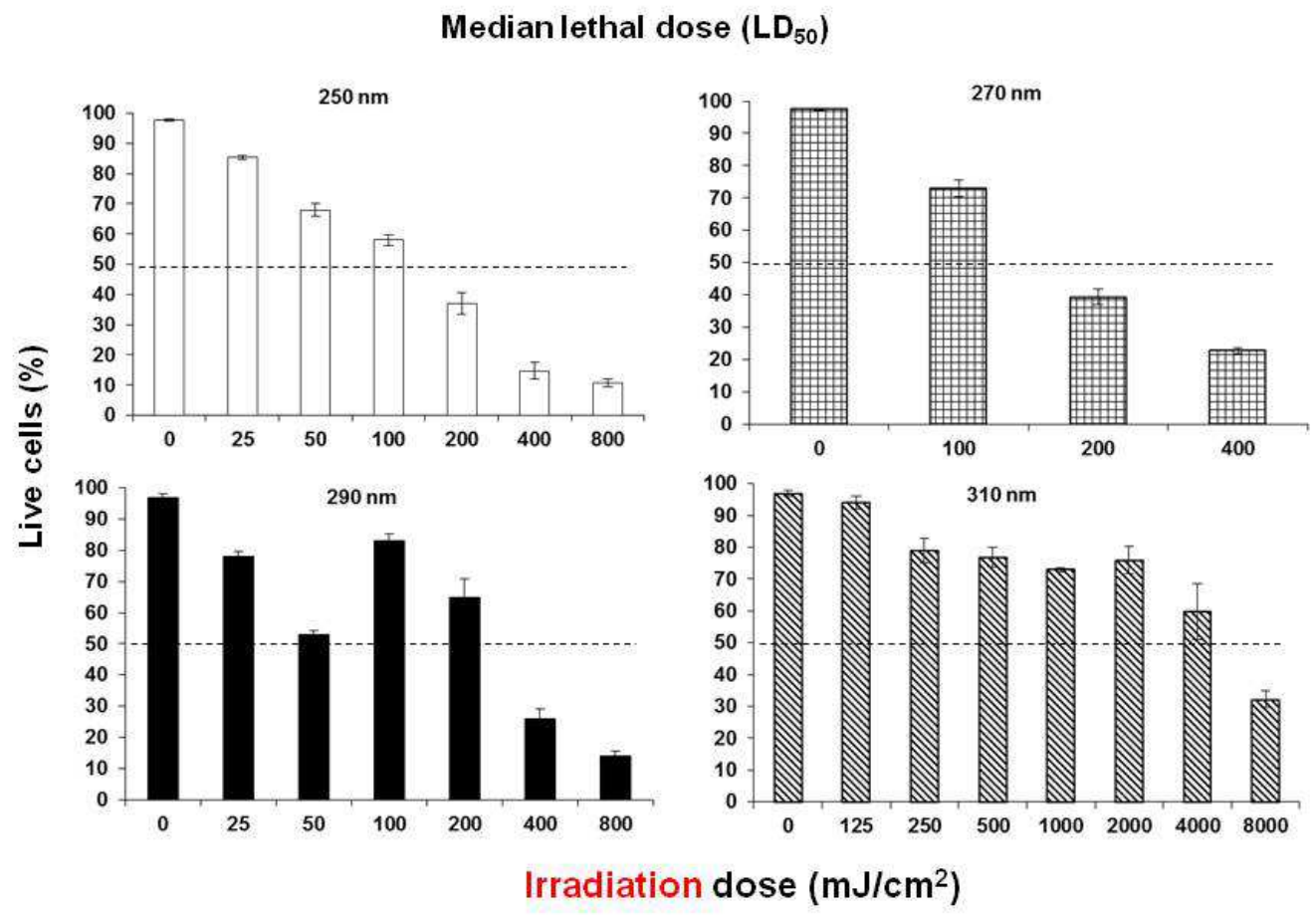

Fig. 2 


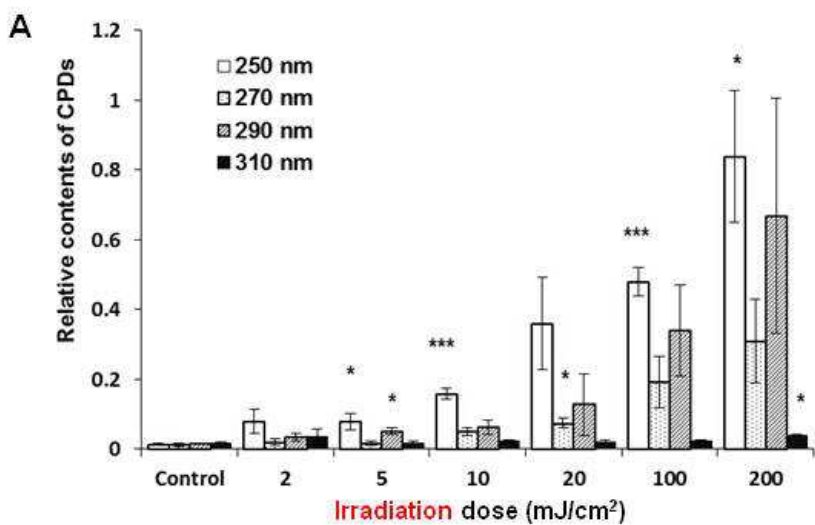

B

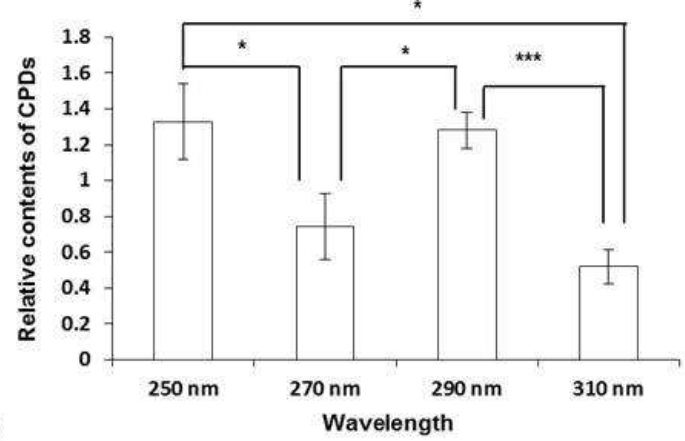

Fig. 3 Wavelength 


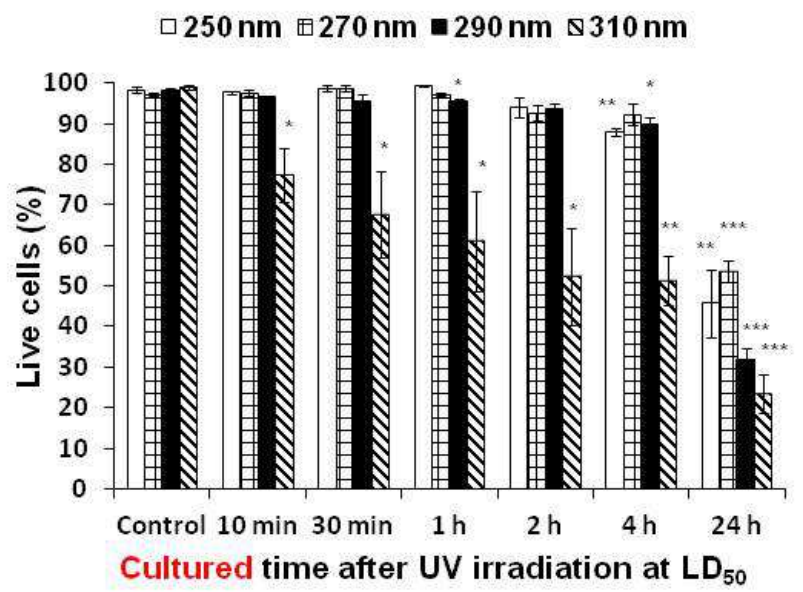

Fig. 4 


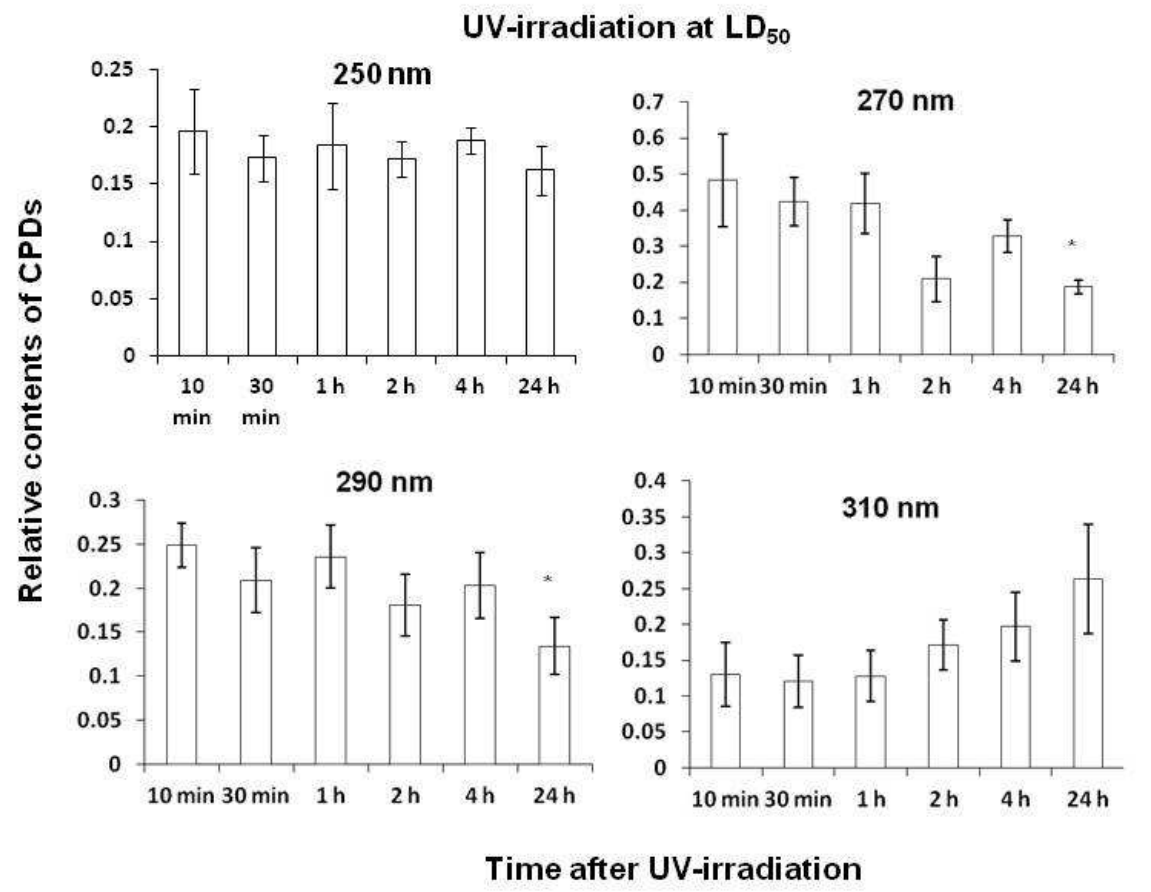

Fig. 5 


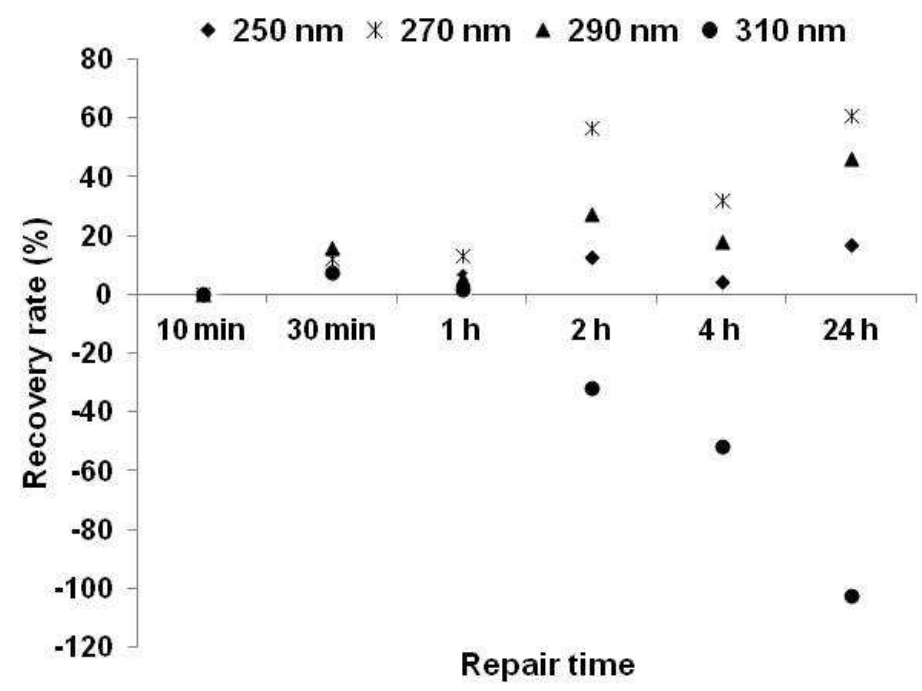

Fig. 6 